\title{
Pyracantha 'Mohave' Fruit Infection by Phytophthora ramorum and Transmission of the Pathogen from Infected Fruit to Roots of Viburnum tinus
}

Paul W. Tooley, Marsha Browning, and Nina Shishkoff, United States Department of Agriculture-Agricultural Research Service Foreign Disease-Weed Science Research Unit, Ft. Detrick, MD 21702

\begin{abstract}
Tooley, P. W., Browning, M., and Shishkoff, N. 2016. Pyracantha 'Mohave' fruit infection by Phytophthora ramorum and transmission of the pathogen from infected fruit to roots of Viburnum tinus. Plant Dis. 100:555-560.

Colonization of the fleshy fruit of Cornus florida, C. kousa, Laurus nobilis, Malus hupehensis, and Pyracantha 'Mohave' was observed following inoculation with sporangia of Phytophthora ramorum. However, abundant production of chlamydospores was only observed in the fruit of Pyracantha 'Mohave'. Pyracantha 'Mohave' fruit that had been inoculated with a $P$. ramorum sporangia suspension were placed in pots containing rooted cuttings of Viburnum tinus in a misting tent or in water-filled trays in a climate-controlled greenhouse. Runoff was collected for 24 to 30 days, and roots were plated after the final collection. Mean percent recovery from infected roots was

not significantly different ( $P=0.05$, Tukey's test) between bottomwatered treatments in trays and misted treatments, averaging $58 \%$ for bottom-watered and $54 \%$ for mist treatments. The number of CFU collected in runoff from bottom-watered plants was consistently lower than that obtained from plants held under mist, likely due to desiccation of the fruit. The results show that root infection of $V$. tinus can occur by $P$. ramorum via infected fruit of Pyracantha 'Mohave'. This phenomenon represents a pathway of infection for $P$. ramorum not previously reported, which may play a role in disease epidemiology.
\end{abstract}

Phytophthora ramorum was first observed causing sudden oak death in California forests in the mid-1990s (Rizzo et al. 2002, 2005) and was described as a new species in 2001 (Werres et al. 2001). P. ramorum has now not only caused significant losses to forest resources in the Western United States (Frankel 2008; Grünwald et al. 2012; Hansen 2015) but also causes sudden larch death in the United Kingdom (Brasier and Webber 2010; Webber et al. 2010). Ramorum blight is a major problem affecting nursery stock as well, with quarantine restrictions currently in place to prevent interstate movement of the pathogen (APHIS 2015; California Oak Mortality Task Force 2015; Dart and Chastagner 2007; Goss et al. 2009). To date, there exist four evolutionary lineages of $P$. ramorum (Grünwald et al. 2009; Van Poucke et al. 2012).

A number of Phytophthora spp. are known to infect the fruit or seed of several host species (Erwin and Ribeiro 1996). Avocado fruit can be infected by $P$. cinnamomi and also by $P$. citricola and $P$. hevea (Koike et al. 1987; Perez-Jimenez 2008). Ando et al. (2009) described infection of various cucurbit fruit by $P$. capsici. Upstone (1978) showed that $P$. syringae can cause rotting of apple fruit. Graham et al. (1998) described citrus brown rot caused by $P$. palmivora and P. nicotianae. Several workers (Awuah and Frimpong 2007; Jackson and Newhook 1978; Kumi et al. 1996) have shown that infected cacao pods are an important source of inoculum and that $P$. palmivora can be systemically transmitted from infected pods to cacao seedlings. Kumi et al. (1996) also showed that $P$. palmivora could be isolated from symptomless cacao pods on infected trees. Fruit infection also provides inoculum for P. botryosa on Hevea spp. (Chee 1969). Wen et al. (2000) showed that soybean seed

\section{Corresponding author: P. W. Tooley; E-mail: paul.tooley@ars.usda.gov}

Mention of trade names or commercial products in this publication is solely for the purpose of providing specific information and does not imply recommendation or endorsement by the United States Department of Agriculture.

Accepted for publication 14 September 2015.

http://dx.doi.org/10.1094/PDIS-03-15-0369-RE

This article is in the public domain and not copyrightable. It may be freely reprinted with customary crediting of the source. The American Phytopathological Society, 2016. resulting from inoculation of young seed pods can be infected by $P$. sojae and, when sown, can infect nearby plants.

$P$. ramorum has been reported to sporulate on asymptomatic fruit of several plant species, including Crataegus monogyna, Laurus nobilis, Quercus ilex, Rosa sempervirens, and Smilax aspera (Denman et al. 2008). Fruit inoculation assays were also conducted by Moralejo et al. (2006), who found that fruit of Arbutus unedo, L. nobilis, Pistacia lentiscus, Rhamnus alaternus, and Viburnum tinus were susceptible to Phytophthora ramorum. They also observed that $P$. ramorum was able to colonize the mesocarp and endocarp of berries of Pistacia lentiscus and $R$. alaternus, which are both dispersed by birds.

Each year, Phytophthora ramorum is detected in nurseries in the Eastern United States as the result of movement of plants in the nursery industry (Stokstad 2004). In 2014, P. ramorum was reported in 19 host nurseries located in three regulated states (California, Oregon, and Washington) and four nonregulated states (Maine, New York, Texas, and Virginia) (Hebbar 2014). In Spring 2010, $P$. ramorum was detected on seedlings of $L$. nobilis (Sweetbay or European bay laurel) in a nursery in Lancaster, PA, which had been grown from seed obtained from a $P$. ramorum-infested and Animal and Plant Health Inspection Service (APHIS)-regulated county in California (Hebbar 2010a,b). At that time, APHIS released a note clarifying that the infected plants were found in seedling flats in a commercial greenhouse and not in the forestry environment. It was also stated that the Confirmed Nursery Protocol was completed and that subsequent plant and soil samples were all negative for $P$. ramorum (Hebbar 2010b). In addition, trace-forward investigations of over 45 samples from both Eastern and Western states tested negative (Hebbar 2010a).

L. nobilis has a fleshy fruit and is currently on the APHIS "List of Regulated Hosts and Plants Proven or Associated with Phytophthora ramorum", as is Cornus kousa (kousa dogwood), another species with a fleshy fruit. A wide variety of plant species, including some with fleshy fruit, are commonly shipped within the nursery industry, and it is desirable to know whether seed or fruit of such plants may be able to transmit $P$. ramorum and provide inoculum that can infect aboveground plant parts as well as roots of susceptible host species. Both seed and fruit shipped interstate as well as plants containing seed or fruit potentially infected with $P$. ramorum could be of concern. Because of the positive 2010 detection of $P$. ramorum in the 
Lancaster, PA nursery, APHIS was interested in determining whether a $P$. ramorum pathway could exist via fleshy-seeded plant species shipped from the Western to Eastern United States via the nursery trade. Thus, APHIS requested that we perform research to determine the propensity of such materials to become infected by $P$. ramorum and transmit the disease. In this study, we tested the potential for selected plant species with fleshy fruit to sustain fruit infection by $P$. ramorum. Because only Pyracantha 'Mohave' fruit supported an abundance of $P$. ramorum chlamydospores following inoculation, we further conducted a study to investigate the potential for $P$. ramorum to be transmitted to roots of a susceptible (V. tinus) host via infected Pyracantha 'Mohave' fruit.

\section{Materials and Methods}

Inoculum production and inoculation. Sporangia from six P. ramorum isolates (Table 1) were produced in $1 \%$ soil extract (Tooley et al. 2004). Spores were harvested and combined into a single spore suspension, with the concentration adjusted to 2,000 sporangia/ml. Fruit of selected plant species known to contain fleshy fruit were collected from local sources (C. florida, C. kousa, Malus hupehensis, and Pyracantha 'Mohave'), while L. nobilis fruit were obtained from colleagues in California. Additional Pyracantha 'Mohave' fruit was collected from plants obtained commercially and maintained in a greenhouse. Collected fruit were held in Ziploc bags at $4^{\circ} \mathrm{C}$ until use. Batches of approximately 100 fruit were surface disinfested in $0.525 \%$ sodium hypochlorite for $5 \mathrm{~min}$, triple rinsed in sterile reverse osmosic (RO) water, then immersed in either $250 \mathrm{ml}$ of a $P$. ramorum sporangia suspension or $1 \%$ soil extract control for $1 \mathrm{~h}$. Fruit were then collected and transferred to Ziploc bags containing moistened vermiculite. The bags were held at $20^{\circ} \mathrm{C}$ for 2 days to allow for infection and then stratified in the dark at $4^{\circ} \mathrm{C}$ for 200 to 300 days. Fruit were rinsed clean of vermiculite prior to use.

Runoff assay. We used the system described by Shishkoff (2011), which employs host species V. tinus (Ginetti et al. 2014) to quantify the amount of $P$. ramorum inoculum present in runoff (Fig. 1). Stem cuttings of $V$. tinus were rooted in Turface MVP (calcined, montmorillonite clay; Profile Products LLC, Buffalo Grove, IL) under

Table 1. Isolates of Phytophthora ramorum used in these studies

\begin{tabular}{llll}
\hline Isolate & Host genus & \multicolumn{1}{c}{ Source } & Lineage $^{\mathbf{z}}$ \\
\hline NS-5C & Camellia & California & NA1 \\
WSDA 1772 & Viburnum & Washington State & NA1 \\
09-053 & Rhododendron & California & NA2 \\
05-166 & Rhododendron & Washington State & NA2 \\
BBA 9/95 & Rhododendron & Germany & EU1 \\
06-021 & Pieris & Oregon & EU1 \\
\hline
\end{tabular}

${ }^{\mathrm{z}}$ Clonal lineage as described by Grünwald et al. (2009)

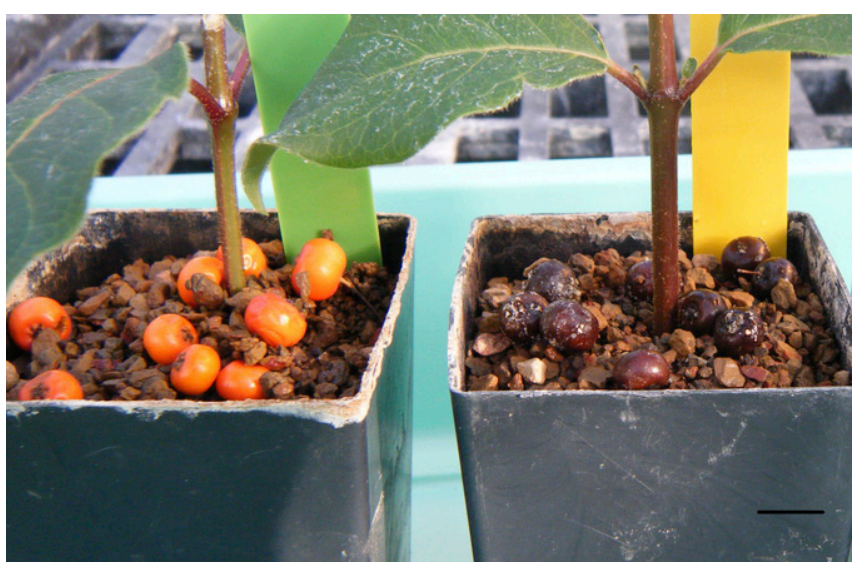

Fig. 1. Healthy (left) and diseased (right) fruit of Pyracantha 'Mohave' on surface of Turface containing plants of Viburnum tinus for assay to determine amount of Phytophthora ramorum inoculum present in runoff. Bar represents $1 \mathrm{~cm}$ mist. Containers were Anderson plant bands (square pots; $5.5 \mathrm{~cm}$ wide at the top, $5.0 \mathrm{~cm}$ wide at the bottom, and $7.5 \mathrm{~cm}$ high) fitted with a plastic mesh liner to hold in the Turface. Once the cuttings had rooted (2 to 3 months), 15 plants (1 per pot) were placed in a mist tent outfitted with fogging nozzles set to activate for $15 \mathrm{~s}$ every $12 \mathrm{~min}$, and 15 plants were set up in trays in a climate-controlled greenhouse at $20^{\circ} \mathrm{C}$. Water levels in trays were maintained at a depth of approximately 2 to $3 \mathrm{~cm}$. Six plants at each location received 10 inoculated fruit or 10 noninoculated fruit. The remaining three plants served as negative controls. Runoff from roots in the stored fruit experiments was collected at 1, 3, 6, 8, 10, 13, 15, and 24 days. A 50-ml conical centrifuge tube was positioned at a corner of the pot and, with the pot tilted toward the tube, $15 \mathrm{ml}$ of water was added to the medium surface. Runoff was collected, tilting the pot to collect from each corner, until a volume of $15 \mathrm{ml}$ was reached. When necessary, the pot was agitated gently up and down to increase the volume of runoff. This process was repeated, collecting runoff from each pot. For the plants held in trays, excess water was allowed to drain from the pots prior to flushing the Turface medium with additional water and collecting the runoff. Tubes containing runoff were vortexed, and $1 \mathrm{ml}$ of the suspension was added to each of three 100-by15-mm petri dishes containing PARPH (pimaricin-ampicillin-rifampicinpentachloronitrobenzene-hymexazol) selective medium (Jeffers and Martin 1986). The dishes were tilted to distribute the suspension over the medium surface. Plates were incubated unwrapped in a $20^{\circ} \mathrm{C}$ incubator in the dark. Plates were examined and colonies marked on the underside of the dish over a 7-day period. The number of colonies of $P$. ramorum observed on each plate was recorded, combined, and
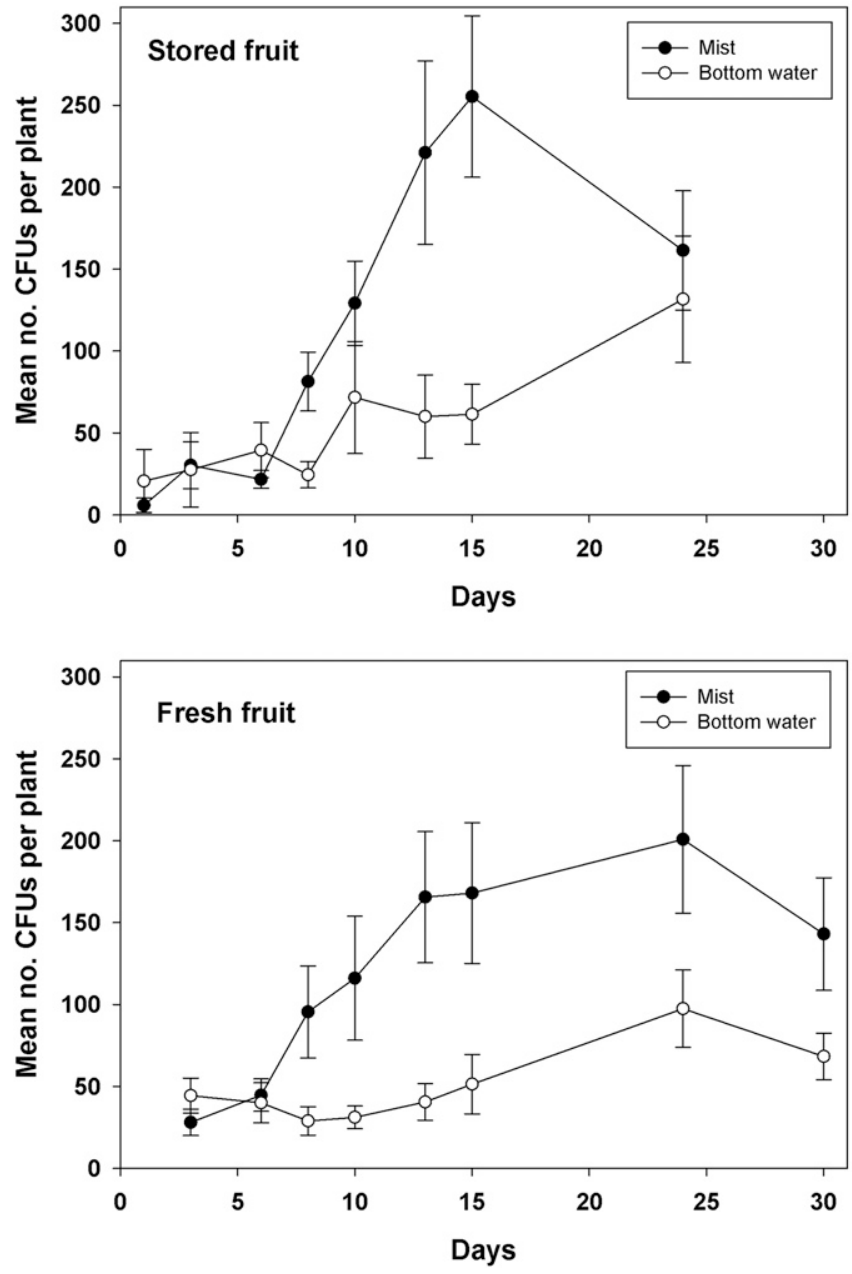

Fig. 2. Number of CFU per plant contained in runoff from Viburnum tinus plants inoculated with Phytophthora ramorum-infected fruit of Pyracantha 'Mohave' for stored (top) and fresh fruit (bottom). Data are means of three experiments, with six plants assayed in each experiment. Bars represent standard errors. 
multiplied by 5 to give the number of CFU in the total $15 \mathrm{ml}$ of runoff collected from each plant. Three experiments were performed, and runoff data are presented as the total number of CFU observed per plant for each date. Three experiments were also performed using freshly harvested fruit rather than stored fruit. Fruit was immersed in the $P$. ramorum sporangia suspension $(2,000$ sporangia/ml $)$ for $24 \mathrm{~h}$, then transferred to the Turface surface. Runoff was collected as described above on days 3, 6, 8, 10, $13,15,24$, and 30 , and roots were plated after collecting and plating runoff on day 30 .

Root assay. Following the final collection and plating of runoff, roots were rinsed clean of Turface, surface sterilized in $0.26 \%$ sodium hypochlorite for $5 \mathrm{~min}$, and triple-rinsed in RO water. Seven $1-\mathrm{cm}$ root-tip segments were collected at random from each root system and plated on each of three $9 \mathrm{~cm}$-diameter petri dishes filled with PARPH selective medium, with $2 \%$ clarified, buffered V8 juice added, for a total of 21 root segments per plant. Plates were incubated at $20^{\circ} \mathrm{C}$ in darkness and examined for the presence of $P$. ramorum over a 21-day period. Recovery data are presented as the mean percentage of root segments plated per plant from which $P$. ramorum was recovered.

Chlamydospore counts. Direct counts of chlamydospores in 10 stored fruit were made by removing skin and seed and squashing the pulp between a glass slide and coverslip, two squash mounts per fruit. Three batches of 10 diseased fruit (stored, inoculated fruit only) were also homogenized, diluted, and plated on PARPH selective medium. The 10 fruit in each batch were homogenized in a blender in $40 \mathrm{ml}$ of sterile RO water (eight quick bursts) and the volume was then brought up to $80 \mathrm{ml}$ using additional sterile RO water. Then, $1 \mathrm{ml}$ was plated on 9-cm-diameter petri dishes of PARPH, and five counts were performed per batch of fruit. To confirm the ability of Pyracantha 'Mohave' fruit and its contents to support chlamydospore production and germination by $P$. ramorum, an extract was prepared from fruit and inoculated with $P$. ramorum-infested plugs of $10 \%$ V8 juice agar. Pyracantha fruit was removed from storage at $4{ }^{\circ} \mathrm{C}$ in Ziploc bags, surface disinfested with a $0.5 \%$ sodium hypochlorite solution for $10 \mathrm{~min}$, then triple rinsed with sterile $\mathrm{RO}$ water. Approximately $150 \mathrm{~cm}^{3}$ of fruit was placed in a 1-liter beaker and the volume was increased to $400 \mathrm{ml}$ with RO water. The suspension was heated in a microwave for $2 \mathrm{~min}$, then covered with foil and left on a benchtop for a week. The softened fruit was crushed with the back of a spoon and left on a benchtop for one more day. The suspension was then filtered through four layers of Kimwipes and autoclaved. Petri dishes ( 60 by $15 \mathrm{~mm}$ ) were filled with $10 \mathrm{ml}$ of Pyracantha 'Mohave' fruit extract $(0,2,5,10,20$, and $50 \%$ [vol/vol] $)$, four dishes per concentration. Dishes were inoculated with single agar fragments (approximately $2 \mathrm{~mm}$ in diameter) from a 10\% V8 juice agar culture (approximately 14 days old) of P. ramorum isolate NS-5C (Table 1). Plates were wrapped and placed in the dark at $20^{\circ} \mathrm{C}$ for a week, then examined. After 2 weeks of incubation, chlamydospores were mechanically harvested from colonies growing in $2 \%$ fruit extract. Approximately 100 chlamydospores were pipetted in a 1-ml suspension onto five plates of PARPH selective agar medium. Plates were incubated unwrapped in a $20^{\circ} \mathrm{C}$ incubator for 3 days. Counts of germinated chlamydospores were performed, with only those colonies that could be traced back to a germinated chlamydospore being counted.

\section{Results}

$P$. ramorum was recovered from inoculated fleshy fruit of $C$. florida, C. kousa, L. nobilis, M. hupehensis, and Pyracantha 'Mohave' but no chlamydospores were observed in the fruit pulp. Also, no chlamydospores were observed in noninoculated fruit of any plant species. Examination of the fleshy pulp revealed an abundance of chlamydospores only in the fruit of Pyracantha 'Mohave'. Dilution plating results revealed an average of 1,099 CFU/fruit (standard error $26 \mathrm{CFU}$ ), while direct counts revealed an average of 1,707 chlamydospores/fruit (standard error of 150 chlamydospores). Pyracantha fruit exposed to $P$. ramorum sporangia appeared russet brown in color and the pulp was quite soft, whereas fruit which had been exposed to soil extract only and then transferred to vermiculite for cold storage was still red and mostly firm.

For stored fruit, the number of CFU obtained from pots containing V. tinus plants and infected Pyracantha 'Mohave' fruit watered using mist showed increases over time, except for decreases between 3 and 6 days and between 15 and 24 days (Fig. 2, top). CFU from pots watered from the bottom did not show a drop between 15 and 24 days but did show a drop between 6 and 8 days (Fig. 2, top). For fresh fruit (Fig. 2, bottom), the number of CFU per plant for the mist-watering treatment increased up to 24 days, then showed a decrease between 24 and 30 days. The number of CFU for the bottom-watered treatments decreased from day 3 through day 8 , then increased from day 8 until day 24, then again showed a decrease to day 30 (Fig. 2, bottom).

Regression lines were fit and slopes for mist and bottom watering compared within the fresh and stored fruit datasets using analysis of covariance. For both stored and fresh fruit, regression slopes differed significantly $(P=0.05)$ between mist and bottom-watered treatments. Thus, the rate of increase in CFU obtained over days of collection was significantly higher for mist compared with bottom-watered treatments for both stored and fresh fruit. Intercepts did not differ significantly for either group.

For both stored and fresh fruit, results of analysis of variance for CFU showed that significant differences existed for irrigation (mist versus bottom watered) and days of collection but not for fruit (stored versus fresh), nor was there a significant fruit-irrigation interaction (Table 2). Misting treatment resulted in collection of significantly more $P$. ramorum $\mathrm{CFU}$ in runoff compared with bottom watering. Mean values shown for CFU showed no significant differences

Table 3. Mean values for CFU obtained in runoff from Viburnum tinus infected by Phytophthora ramorum-infected Pyracantha 'Mohave' fruit

\begin{tabular}{lcc}
\hline Fruit $^{\mathbf{x}}$ & Irrigation method $^{\mathbf{y}}$ & Mean $^{\mathbf{C F U}}$ \\
\hline Stored & Mist & $116.98 \mathrm{a}$ \\
Fresh & Mist & $110.94 \mathrm{a}$ \\
Stored & Bottom & $58.30 \mathrm{~b}$ \\
Fresh & Bottom & $40.97 \mathrm{~b}$ \\
\hline
\end{tabular}

${ }^{x}$ Freshly collected fruit versus fruit inoculated and stored at $4{ }^{\circ} \mathrm{C}$ until use.

${ }^{y} V$. tinus plants placed under mist in a controlled-environment greenhouse cubicle or bottom watered in a containment greenhouse.

${ }^{\mathrm{z}}$ Means within a column followed by the same letter do not differ significantly via Tukey's test, $P=0.05(n=144)$.

Table 2. Analysis of variance for CFU counted based on independent variables fruit, irrigation, and days of runoff collection

\begin{tabular}{|c|c|c|c|c|c|c|}
\hline Source & Degrees of freedom & Sequential sum of squares & Adjusted sum of squares & Adjusted mean square & $F$ statistic & $P$ value \\
\hline Fruit $^{\mathrm{x}}$ & 1 & 257 & 17,208 & 17,208 & 1.23 & 0.267 \\
\hline Irrigation ${ }^{\mathrm{y}}$ & 1 & 595,791 & 595,791 & 595,791 & 42.73 & 0.000 \\
\hline Days $^{\mathrm{z}}$ & 8 & $1,194,922$ & $1,194,922$ & 149,365 & 10.71 & 0.000 \\
\hline Fruit $\times$ irrigation & 1 & 4,584 & 4,584 & 4,584 & 0.33 & 0.567 \\
\hline Error & 564 & $7,864,274$ & $7,864,274$ & 13,944 & $\ldots$ & $\ldots$ \\
\hline Total & 575 & $9,659,829$ & $\ldots$ & $\ldots$ & $\ldots$ & $\ldots$ \\
\hline
\end{tabular}

${ }^{\mathrm{x}}$ Freshly collected fruit versus fruit inoculated and stored at $4^{\circ} \mathrm{C}$ until use.

y Viburnum tinus plants placed under mist in a controlled-environment greenhouse cubicle or bottom watered in a containment greenhouse.

${ }^{z}$ Days over which runoff was collected from pots of $V$. tinus containing Pyracantha 'Mohave' fruit infected with Phytophthora ramorum. 
between stored and fresh fruit with the mist-watering treatment and no differences for the bottom-watering treatment but differences between mist and bottom watering (Table 3 ). No chlamydospores were observed in plated runoff samples.

In terms of percent recovery from infected $V$. tinus roots, an overall analysis of variance showed highly significant differences between stored and fresh fruit but no significant differences for irrigation (mist versus bottom watered), and no significant fruit-irrigation interaction (Table 4). The mean percent infected roots for fresh fruit was not significantly different by Tukey's test $(P=0.05)$ between mist- and bottom-watered treatments, averaging $58 \%$ for bottom-watered and $54 \%$ for mist-watered treatments (Table 5). Nor was the mean percent infected roots for stored fruit significantly different between mist- and bottom-watered treatments, averaging approximately 24\% for both mist- and bottom-watered treatments (Table 5).

In Pyracantha 'Mohave' fruit extract, colonies were of varying size, with the more concentrated fruit extracts producing the largest colonies. Colonies produced in 50, 20, and $10 \%$ extract were dense with hyphae and pigmented chlamydospores. Less concentrated fruit extracts (5 and $2 \%$ ) produced smaller colonies with fewer mycelia and fewer spores. For the chlamydospores extracted from these colonies and plated on PARPH, nearly $100 \%$ germination was observed. For all experiments, data were analyzed using the general linear models and regression procedures within Minitab 17 (Minitab 2010).

\section{Discussion}

Colonization of the fleshy fruit of C. florida, C. kousa, L. nobilis, $M$. hupehensis, and Pyracantha 'Mohave' collected from local sources was observed following inoculation with sporangia of P. ramorum. However, an abundance of chlamydospores was observed only in the fruit of Pyracantha 'Mohave'. Pyracantha is a common evergreen shrub native to Europe and Southeast Asia which is sold commercially throughout the United States, and 'Mohave' has become a widespread Pyracantha cultivar within the nursery industry (U.S. National Arboretum 1999) and is propagated by some nurseries on the West Coast. Although 'Mohave' has never been reported as a host of $P$. ramorum, Pyracantha koidzumii was reported as a host (Briere et al. 2006) and is one of the parents in the cross that produced 'Mohave' (Egolf 1970). Because 'Mohave' is such a common cultivar and propagated on the West Coast of the United States where Phytophthora ramorum is established, it is possible that it could be exposed to $P$. ramorum and serve as an additional means of inoculum dispersal.

$P$. ramorum disease development is very dependent on environmental conditions (Tooley et al. 2009), and our results were obtained under artificial conditions that provided favorable conditions for the pathogen. In a natural setting, however, it is unclear what role Pyracantha 'Mohave' may play in the epidemiology of P. ramorum. Although the plant is common in many suburban environments, its propensity to come into contact with spores of $P$. ramorum may be limited, unless it is grown in commercial greenhouses or nurseries that also harbor infected $P$. ramorum host species. In the natural environment, it could become infected when growing in the vicinity of $P$. ramorum hosts because sporangia have been found to be generated in large numbers by a variety of host species (Tooley and Browning 2009), most notably California bay laurel (Davidson et al. 2008). It should also be noted that fruit of Pyracantha spp. tend to remain on the plant throughout the winter months and not fall easily to the ground where infected fruit might provide chlamydospore or sporangial inoculum. Birds, however, are known to use Pyracantha berries as a food source, and could spread the pathogen, because it has been found that spores of other fungal species (Warner and French 1970) as well as chlamydospores of P. cinnamomi (Keast and Walsh 1979) can be disseminated by birds.

Although many Phytophthora spp. are known to cause fruit rots on different hosts (Erwin and Ribeiro 1996), the transmission of disease from infected fruit on the soil surface to host roots has not, to our knowledge, been shown. Our results show that root infection of a susceptible host can occur by $P$. ramorum via infected fruit of Pyracantha 'Mohave'. This phenomenon represents a pathway of infection for $P$. ramorum not previously reported, which may play a role in disease epidemiology. An average of 1,099 CFU/fruit were obtained when homogenized infected fruit was dilution plated, while 1,707 chlamydospores per infected fruit were counted by direct counting under the microscope. The number obtained by dilution plating may be lower than that obtained by direct counting due to the fact that chlamydospores would have had to germinate on the PARPH selective medium to be counted, and germination rates of $P$. ramorum chlamydospores are known to vary widely (Tooley et al. 2014). The direct count number may also underestimate the total number of chlamydospores present in infected fruit, because some chlamydospores adhered to or were obstructed by the skin of the fruit, rendering them uncountable. Also, the number of CFU collected in runoff from plants held in trays of water was consistently lower than from plants held under mist, likely due to desiccation of the fruit. Considerable air movement in the climate-controlled greenhouse where these experiments were performed resulted in some drying of the Turface medium surface.

It is unclear how much of the inoculum gathered in runoff was due to production of propagules by $P$. ramorum in diseased fruit placed on the medium surface as opposed to the production of propagules by $P$. ramorum in diseased roots. Shishkoff (2009) reported that the production of $P$. ramorum inoculum from a diseased lilac (Syringa vulgaris) leaf maintained on the potting mix surface continued throughout the 22-day duration of the experiment when overhead irrigation was used. Recovery of $P$. ramorum from roots of $V$. tinus plants receiving diseased Pyracantha fruit confirms that the roots were colonized and, thus, it is likely that they also played a role in inoculum production. It is known, for example, that $P$. ramorum

Table 5. Mean values for percent recovery for roots of Viburnum tinus infected by Phytophthora ramorum-infected Pyracantha 'Mohave' fruit

\begin{tabular}{lcl}
\hline Fruit $^{\mathbf{x}}$ & Irrigation method $^{\mathbf{y}}$ & Mean $^{\mathbf{z}}$ \\
\hline Fresh & Bottom & $58.25 \mathrm{a}$ \\
Fresh & Mist & $54.13 \mathrm{a}$ \\
Stored & Bottom & $24.87 \mathrm{~b}$ \\
Stored & Mist & $24.60 \mathrm{~b}$ \\
\hline
\end{tabular}

${ }^{\mathrm{x}}$ Freshly collected fruit versus fruit inoculated and stored at $4^{\circ} \mathrm{C}$ until use.

y Viburnum tinus plants placed under mist in a controlled-environment greenhouse cubicle or bottom watered in a containment greenhouse.

${ }^{z}$ Means within a column followed by the same letter do not differ significantly via Tukey's test, $P=0.05(n=18)$.

Table 4. Analysis of variance for percent recovery from infected roots, using adjusted sums of squares for tests

\begin{tabular}{|c|c|c|c|c|c|c|}
\hline Source & DF & Sequential sum of squares & Adjusted sum of squares & Adjusted mean square & $F$ value & $P$ value \\
\hline Fruit ${ }^{\mathrm{x}}$ & 1 & $17,627.1$ & $17,554.0$ & $17,554.0$ & 28.91 & 0.000 \\
\hline Irrigation ${ }^{\mathrm{y}}$ & 1 & 83.2 & 85.3 & 85.3 & 0.14 & 0.709 \\
\hline Fruit $\times$ irrigation ${ }^{z}$ & 1 & 66.0 & 66.0 & 66.0 & 0.11 & 0.743 \\
\hline Error & 67 & $40,685.6$ & $40,685.6$ & 607.2 & $\ldots$ & $\ldots$ \\
\hline Total & 70 & $58,461.9$ & $\ldots$ & $\ldots$ & $\ldots$ & $\ldots$ \\
\hline
\end{tabular}

${ }^{\mathrm{x}}$ Freshly collected fruit versus fruit inoculated and stored at $4^{\circ} \mathrm{C}$ until use.

y Viburnum tinus plants placed under mist in a controlled-environment greenhouse cubicle or bottom watered in a containment greenhouse.

${ }^{\mathrm{z}}$ Days over which runoff was collected from pots of $V$. tinus containing Pyracantha 'Mohave' fruit infected with Phytophthora ramorum. 
sporangia form in abundance on infected roots (Shishkoff 2007). We observed the root systems of some of the infected plants to be so deteriorated that few roots were left to sample and plate. Although we do not have direct evidence, we presume that chlamydospores in fruit placed on the soil surface gave rise to sporangia that washed down and infected the roots, and that CFU obtained in runoff represented largely sporangia.

The finding that $P$. ramorum can infect fruit of and be transmitted to the root systems of susceptible host plants is significant, in that it represents a previously undescribed pathway of spread for this damaging pathogen. Regulators will have to consider fruit transmission of $P$. ramorum as a possibility allowing for spread of the disease, as we have shown to occur with Pyracantha 'Mohave', an ornamental commonly grown and transported within the nursery industry. Infected fruit containing numerous chlamydospores could serve as a mechanism for spreading the disease to new areas. Examination of the potential for colonization of the fruit of additional $P$. ramorum hosts (APHIS 2013) is desirable to determine whether they can serve as reservoirs of inoculum and contribute to disease epidemics in nurseries or natural ecosystems. Thus, the role of fruit infection in the epidemiology of diseases caused by other Phytophthora spp. also needs to be further explored.

\section{Acknowledgments}

We thank N. Grünwald, S. Werres, and G. Chastagner for providing some of the isolates of $P$. ramorum used in these studies; and L. Englander and K. Kosta for the collection of fruit.

\section{Literature Cited}

Ando, K., Hammar, S., and Grumet, R. 2009. Age-related resistance of diverse cucurbit fruit to infection by Phytophthora capsici. J. Am. Soc. Hortic. Sci. 134:176-182.

APHIS. 2013. APHIS list of regulated hosts and plants proven or associated with Phytophthora ramorum, revised August 2013. United States Department of Agriculture Animal and Plant Health Inspection Service Plant Pest Prog. Inf. Pest List. United States Department of Agriculture, Washington, DC.

APHIS. 2015. Phytophthora ramorum. Online publication. United States Department of Agriculture Animal and Plant Health Inspection Service-Plant Protection and Quarantine. https:/www.aphis.usda.gov/wps/portal/aphis/ ourfocus/importexport?urile=wcm $\% 3$ apath $\% 3 \mathrm{a} \% 2$ Faphis_content_library $\%$ 2Fsa_our_focus $\% 2$ Fsa_plant_health $\% 2$ Fsa_domestic_pests_and_diseases $\%$ 2Fsa_pests_and_diseases\%2Fsa_plant_disease $\% 2 \mathrm{Fsa}$ _pram $\% 2 \mathrm{Fct} \_$phytophthora ramorum_sudden_oak_death

Awuah, R. T., and Frimpong, M. 2007. Investigation into the seed-borne nature and seed to seedling transmission of Phytophthora in cocoa. J. Sci. Technol. Ghana 27:9-16.

Brasier, C., and Webber, J. 2010. Plant pathology: Sudden larch death. Nature 466: 824-825

Briere, S. C., Llewellyn, S., and Kristjansson, G. 2006. First report of Pyracantha koidzumii as a host for Phytophthora ramorum. In: Proc. Sudden Oak Death Second Sci. Symp.: The State of our Knowledge. Gen. Tech. Rep. PSWGTR-196. U.S. Department of Agriculture, Forest Service, Pacific Southwest Research Station, Albany, CA.

California Oak Mortality Task Force. 2015. Regulations. http://www. suddenoakdeath.org/diagnosis-and-management/regulations/

Chee, K. H. 1969. Variability of Phytophthora species from Hevea brasiliensis. Trans. Br. Mycol. Soc. 52:425-436.

Dart, N. L., and Chastagner, G. A. 2007. Estimated economic losses associated with the destruction of plants due to Phytophthora ramorum quarantine efforts in Washington State. Online publication. Plant Health Prog. doi:10.1094/PHP-2007-0508-02-RS

Davidson, J. M., Patterson, H. A., and Rizzo, D. M. 2008. Sources of inoculum for Phytophthora ramorum in a redwood forest. Phytopathology 98:860-866.

Denman, S., Moralejo, E., Kirk, S. A., Orton, E., and Whybrow, A. 2008. Sporulation of Phytophthora ramorum and P. kernoviae on asymptomatic foliage and fruit. Pages 201-207 in: Proc. Sudden Oak Death Third Sci. Symp. S. J. Frankel, J. T. Kliejunas, and K. M. Palmieri, tech. coords. Gen. Tech. Rep. PSW-GTR-214. U.S. Department of Agriculture, Forest Service, Pacific Southwest Research Station, Albany, CA.

Egolf, D. R. 1970. Pyracantha 'Mohave', a new cultivar (Rosaceae). Baileya 17: 79-82.

Erwin, D. C., and Ribeiro, O. K. 1996. Phytophthora Diseases Worldwide. American Phytopathological Society, St. Paul, MN.

Frankel, S. 2008. Sudden oak death and Phytophthora ramorum in the USA: A management challenge. Australas. Plant Pathol. 37:19-25.

Ginetti, B., Carmignani, S., Ragazzi, A., Werres, S., and Moricca, S. 2014. Foliar blight and shoot dieback caused by Phytophthora ramorum on Viburnum tinus in the Pistoia area, Tuscany, Central Italy. Plant Dis. 98:423.
Goss, E. M., Larson, M., Chastagner, G. A., Givens, D. R., and Grünwald, N. J. 2009. Population genetic analysis infers migration pathways of Phytophthora ramorum in US nurseries. PLoS Pathog. 5:e1000583

Graham, J. H., Timmer, L. W., Drouillard, D., and Peever, T. L. 1998 Characterization of Phytophthora spp. causing outbreaks of citrus brown rot in Florida. Phytopathology 88:724-729.

Grünwald, N. J., Garbelotto, M., Goss, E. M., Heungens, K., and Prospero, S. 2012. Emergence of the sudden oak death pathogen Phytophthora ramorum. Trends Microbiol. 20:131-138.

Grünwald, N. J., Goss, E. M., Ivors, K., Garbelotto, M., Martin, F. N., Prospero, S. Hansen, E., Bonants, P. J. M., Hamelin, R. C., Chastagner, G., Werres, S., Rizzo, D. M., Abad, G., Beales, P., Bilodeau, G. J., Blomquist, C. L., Brasier, C., Briere, S. C., Chandelier, A., Davidson, J. M., Denman, S., Elliott, M., Frankel, S. J., Goheen, E. M., deGruyter, H., Heungens, K., James, D., Kanaskie, A., McWilliams, M. G., Man in 't Veld, W., Moralejo, E., Osterbauer, N.K., Palm, M. E., Parke, J. L., Perez Sierra, A. M., Shamoun, S. F., Shishkoff, N., Tooley, P. W., Vettraino, A. M., Webber, J., and Widmer, T. L. 2009. Standardizing the nomenclature for clonal lineages of the sudden oak death pathogen, Phytophthora ramorum. Phytopathology 99:792-795.

Hansen, E. 2015. Phytophthora species emerging as pathogens of forest trees. Curr. For. Rep. 1:16-24.

Hebbar, P. K. 2010a. APHIS Phytophthora ramorum program 2010, 1st quarter summary. Online publication. Animal and Plant Health Inspection Service. https://www.aphis.usda.gov/plant_health/plant_pest_info/pram/downloads/updates/ 2010/programupdate-2010-qtr1.pdf

Hebbar, P. K. 2010b. APHIS Phytophthora ramorum program 2010, 4th quarter summary. Online publication. Animal and Plant Health Inspection Service. https://www.aphis.usda.gov/plant_health/plant_pest_info/pram/downloads/updates/ 2010/programupdate-2010-qtr4.pdf

Hebbar, P. K. 2014. APHIS Phytophthora ramorum program 2014, 4th quarter summary. Online publication. Animal and Plant Health Inspection Service. https://www.aphis.usda.gov/plant_health/plant_pest_info/pram/downloads/updates/ 2014/4thqtr2014.pdf

Jackson, G. V. H., and Newhook, F. J. 1978. Sources of Phytophthora palmivora inoculum in Solomon Islands cocoa plantations. Trans. Br. Mycol. Soc. 71: 239-249.

Jeffers, S. N., and Martin, S. B. 1986. Comparison of two media selective for Phytophthora and Pythium spp. Plant Dis. 70:1038-1043.

Keast, D., and Walsh, L. G. 1979. Passage and survival of chlamydospores of Phytophthora cinnamomi Rands, the causal agent of forest dieback disease, through the gastrointestinal tracts of termites and wild birds. Appl. Environ. Microbiol. 37:661-664.

Koike, S. T., Ouimette, D. G., and Coffey, M. D. 1987. First report of avocado fruit rot caused by Phytophthora citricola in California. Plant Dis. 71:1045.

Kumi, M. A., Wolffhechel, I., Hansen, H. J., and Mathur, S. B. 1996. Seed transmission of Phytophthora in cacao. Seed Science Technol. 24:593-595.

Minitab. 2010. Minitab 17 Statistical Software. Online publication. Minitab, Inc., State College, PA. http://www.minitab.com/en-us/

Moralejo, E., Puig, M., Garcia, J. A., and Descals, E. 2006. Stromata, sporangiomata and chlamydosori of Phytophthora ramorum on inoculated Mediterranean woody plants. Mycol. Res. 110:1323-1332.

U.S. National Arboretum. 1999. Pyracantha 'Mohave'. Online publication. Floral and Nursery Plants Research Unit, U.S. Natl. Arboretum, U.S. Dep. Agric. Agric. Res. Serv. http://www.usna.usda.gov/Newintro/mohave.pdf

Perez-Jimenez, R. M. 2008. Significant avocado diseases caused by fungi and oomycetes. Eur. J. Plant Sci. Biotechnol. 2:1-24.

Rizzo, D. M., Garbelotto, M., Davidson, J. M., Slaughter, G. W., and Koike, S. T. 2002. Phytophthora ramorum as the cause of extensive mortality of Quercus spp. and Lithocarpus densiflorus in California. Plant Dis. 86:205-214.

Rizzo, D. M., Garbelotto, M., and Hansen, E. M. 2005. Phytophthora ramorum: Integrative research and management of an emerging pathogen in California and Oregon forests. Annu. Rev. Phytopathol. 43:309-335.

Shishkoff, N. 2007. Persistence of Phytophthora ramorum in soil mix and roots of nursery ornamentals. Plant Dis. 91:1245-1249.

Shishkoff, N. 2009. Propagule production by Phytophthora ramorum on Lilac (Syringa vulgaris) leaf tissue left on the surface of potting mix in nursery pots. Plant Dis. 93:475-480.

Shishkoff, N. 2011. A test system to quantify inoculum in runoff from Phytophthora ramorum-infected plant roots. Phytopathology 101:1457-1464.

Stokstad, E. 2004. Nurseries may have shipped sudden oak death pathogen nationwide. Science 303:1959.

Tooley, P. W., and Browning, M. 2009. Susceptibility to Phytophthora ramorum and inoculum production potential of some common eastern forest understory plant species. Plant Dis. 93:249-256.

Tooley, P. W., Browning, M., Kyde, K. L., and Berner, D. 2009. Effect of temperature and moisture period on infection of Rhododendron 'Cunningham's White' by Phytophthora ramorum. Phytopathology 99:1045-1052.

Tooley, P. W., Browning, M., and Leighty, R. M. 2014. The effect of temperature on germination of chlamydospores of Phytophthora ramorum. Mycologia 106: 424-430.

Tooley, P. W., Kyde, K. L., and Englander, L. 2004. Susceptibility of selected ericaceous ornamental host species to Phytophthora ramorum. Plant Dis. 88 993-999. 
Upstone, M. E. 1978. Phytophthora syringae fruit rot of apples. Plant Pathol. 27: 24-30

Van Poucke, K., Franceschini, S., Webber, J. F., Vercauteren, A., Turner, J. A., McCracken, A. R., Heungens, K., and Brasier, C. M. 2012. Discovery of a fourth evolutionary lineage of Phytophthora ramorum: EU2. Fungal Biol. 116:1178-1191.

Warner, G. M., and French, D. W. 1970. Dissemination of fungi by migratory birds: Survival and recovery of fungi from birds. Can. J. Bot. 48:907-910
Webber, J. F., Mullett, M., and Brasier, C. M. 2010. Dieback and mortality of plantation Japanese larch (Larix kaempferi) associated with infection by Phytophthora ramorum. New Dis. Rep. 22:19

Wen, J., Li, Z., and Zhou, Y. 2000. Transmission of Phytophthora rot of soybean Soybean Sci. 19:223-228.

Werres, S., Marwitz, R., Man in 't Veld, W. A., De Cock, A. W. A. M., Bonants, P. J. M., De Weerdt, M., Themann, K., Ilieva, E., and Baayen, R. P. 2001 Phytophthora ramorum sp. nov., a new pathogen on Rhododendron and Viburnum. Mycol. Res. 105:1155-1165. 